\title{
Case Studies
}

Introduction

The Anti-isolationist Cartoons of Dr Seuss 8

John Hersey's Hiroshima (1946) 23

Modern Woman: The Lost Sex (1947) 30

1. Fiction and Journalism

William Faulkner's Banquet Speech, 1949 Nobel Prize in Literature $\quad 36$

Richard Wright's Native Son (1940) 40

Life Magazine and 'The American Century' 51

2. Radio and Music

Eddie 'Rochester' Anderson 78

The International Sweethearts of Rhythm $\quad 82$

Bob Hope’s USO Tours 89

3. Theatre and Film

Anna Lucasta and the American Negro Theatre 106

Orson Welles and Citizen Kane 114

HUAC in Hollywood 121

4. Visual Art, Serious and Popular

Peggy Guggenheim and Art of This Century 143

Horace Pippin, Self-taught Master of the 1940s 155

The 'Critical Internationalism' of Johnny Everyman 166

5. The Arts of Sacrifice and Consumption

I Am an American Day (1940-52) 180

The 1939-40 New York World's Fair 185

Russel Wright's American Modern 189 
Conclusion: The 1940s in the Contemporary American Imagination

Andy Rooney's My War (1995)

HBO's Band of Brothers (2001)

The Atomic Café (1982) 